BNL-68852

Informal Report

\title{
Biodiesel Blends in Space Heating Equipment
}

\author{
C.R. Krishna \\ DECEMBER 2001
}

\begin{abstract}
Prepared for:
National Renewable Energy Laboratory

Program Manager: Dr. Shaine K. Tyson
\end{abstract}

United States Department of Energy

Under Contract No. DE-AC02-98CH10886

Brookhaven National Laboratory

Upton, NY 11973-5000 


\section{Table of Contents}

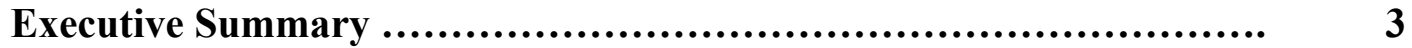

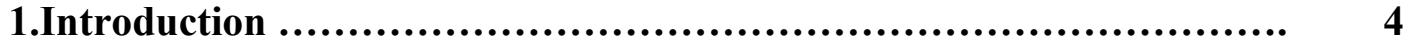

2. Background ......................................................... 4

3. Present Project ......................................................... 6

4. Recommendations .................................................. 12

5. References

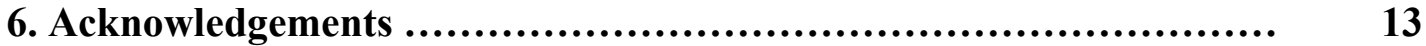

Figures

Fig. 1 Test Setup for Transient Tests .................................... 14

Fig. 2 Commercial boiler Set up ...................................... 15

Fig. 3 Flash Point of Biodiesel blends in Fuel Oil ......................... 16

Fig. 4 Viscosity Change with Biodiesel in Blend ......................... 16

Fig. 5 Flash Points for Biodiesel-Kerosine Blends ...................... 17

Fig. 6 Pour Points for Biodiesel-Fuel oil Blends ........................ 17

Fig. 7 Schematic of a Residential Boiler Fuel System .................... 18

Fig. 8 Carbon monoxide Transient for \#2 oil and B10 .................. 18

Fig. 9 Carbon monoxide Transient for \#2 oil and B20 ................... 19

Fig. 10 Carbon monoxide Transient for $\# 2$ oil and B30 ................ 20

Fig. 11 Carbon monoxide Transient for \#2 oil and BK50 .............. 20

Fig. 12 Carbon monoxide Transient for \#2 oil and B100 ................ 21

Fig. 13 Carbon monoxide for B10 ........................................ 21

Fig. 14 Carbon monoxide for B20 ..................................... 22

Fig. 15 Carbon monoxide for BK50 .................................. 22

Fig. 16 Carbon monoxide for B100 .................................... 23

Fig. 17 NOx in Residential Boiler ....................................... 24

Fig. 18 NOx in the Commercial Boiler ................................. 25

Tables

Table 1 Sulfur and Nitrogen Content of Blends ........................ 26

Table 2 Cad Cell Resistance ............................................ 26 


\section{Executive Summary}

Biodiesel is a 'diesel-like' fuel that is derived from processing vegetable oils from various sources, such as soy oil, rapeseed or canola oil, and also waste vegetable oils resulting from cooking use. Brookhaven National laboratory initiated an evaluation of the performance of blends of biodiesel and home heating oil in space heating applications under the sponsorship of the Department of Energy (DoE) through the National Renewables Energy Laboratory (NREL). This report is a result of this work performed in the laboratory.

A number of blends of varying amounts of a biodiesel in home heating fuel were tested in both a residential heating system and a commercial size boiler. The results demonstrate that blends of biodiesel and heating oil can be used with few or no modifications to the equipment or operating practices in space heating. The results also showed that there were environmental benefits from the biodiesel addition in terms of reductions in smoke and in Nitrogen Oxides (NOx). The latter result was particularly surprising and of course welcome, in view of the previous results in diesel engines where no changes had been seen. Residential size combustion equipment is presently not subject to NOx regulation. If reductions in NOx similar to those observed here hold up in larger size (commercial and industrial) boilers, a significant increase in the use of biodiesel-like fuel blends could become possible. 


\section{Biodiesel Blends in Space Heating Equipment}

\subsection{Introduction}

Biodiesel is a 'diesel-like' fuel that is derived from processing vegetable oils from various sources, such as soy oil, rapeseed or canola oil, and also waste vegetable oils resulting from cooking use. The American Society for Testing and Materials (ASTM) is in the process of finalizing a standard for biodiesel (PS 121). A German standard exists (DIN 51606) and a European standard is in preparation. In view of its similarity to diesel fuel, it has been tested fairly extensively in diesel engines. It has not been as widely tested for boiler applications and in residential heating applications.

Brookhaven National laboratory has initiated an evaluation of the performance of blends of biodiesel and home heating oil in space heating applications under the sponsorship of the Department of Energy (DoE) through the National Renewables Energy Laboratory (NREL). The work will be continued under the sponsorship of New York State Energy Research and Development Administration (NYSERDA). This report presents the results obtained from the tasks performed under NREL sponsorship. The DoE program manager is Dr. K. Shaine Tyson.

If it can be demonstrated that blends of biodiesel and heating oil can be used with few or no modifications to the equipment or operating practices in space heating, substantial benefits may be realizable. A fraction of the national fuel needs could be met with domestic and potentially locally produced agricultural based fuels, which are renewable and environmentally beneficial, being sulfur-free, biodegradable, and nontoxic. It could also contribute to fuel source diversity for space heating, reducing the vulnerability to petroleum market disruptions, and providing a cushion for the effects of future sudden price spikes.

\subsection{Background}

\section{2.l Biodiesel}

Biodiesel is a name applied to fuels manufactured by the esterification of renewable oils, fats and fatty acids. The fatty acids may be derived from vegetable oils such as soybean or rapeseed (canola), rendered tallow, or waste materials such as cooking and trap greases [1]. The resulting product has $10-12 \%$ oxygen by weight and little or no sulfur and has been shown to reduce the particulate emission in diesel engine use. Chemically, it is essentially non-aromatic and has a higher cetane number than normal diesel fuel. It has a heating value of about 133,000 BTU per gallon compared to about 140,000 BTU per gallon of \#2 fuel oil. It has a slightly higher density. Neat (100\%) biodiesel also has higher cloud and pour point temperatures than home heating oil. Biodiesel is completely miscible with home heating oil and so blends can be easily generated if mixed well so that the differences in density do not lead to stratification. In passing, a matter of common terminology should be noted. The blends are made in volumetric percentages and designated as $\mathrm{B} X$ where $X$ is the percentage of biodiesel in that blend of biodiesel in petroleum diesel. For example, B10 has 10\% biodiesel and B100 is neat biodiesel. 


\subsection{Brief Review of Past Work}

Biodiesel has been quite extensively tested in diesel engines [1] and in fact is sold at approximately 900 gas stations in Germany [2]. This work will not be reviewed here, as it is not immediately relevant to the space heating application. The only past work of such relevance was done by the R.W. Beckett corporation under the sponsorship of $\mathrm{Ag}$ Environmental Products in 1993. The report on this proprietary work [3] was made available through the National Biodiesel Board (NBB) and Dr. K. Shaine Tyson. Beckett Corp. conducted some material compatibility tests and combustion performance tests using neat biodiesel (B100). The material compatibility tests consisted of leaving samples of the pump shaft seals in jars of B100 and fuel oil for 120 hours after which they were heated to $120^{\circ} \mathrm{F}$ for 72 hours. They were checked for swelling after the soaking and after the heating. Samples of plastics, label, gaskets and painted metal were soaked in the B100 for extended periods of time. The combustion tests were performed using a 3 section wet-base boiler and a Beckett retention head burner. Steady state tests were conducted and the switch to firing B100 occurred without changing any burner setting. Their summary is reproduced below [3].

A. "Due to the lack of varnish stains on the inside of the glass jar containing SoyDiesel when heated to $200^{\circ} \mathrm{F}$ for 72 hours, we predict that SoyDiesel would tend to minimize the varnishing of the nozzle caused by the proximity of the electrodes to nozzle as seen with fuel oil. Long term cycling would be required to verify this theory.

B. Although we were unable to test cold SoyDiesel it would seem that, due to the higher viscosity of SoyDiesel compared to fuel oil, SoyDiesel would pose problems lighting off when cold. A nozzle line heater would probably assist the lighting of SoyDiesel.

C. Based on our testing, it would appear that the plastics we use on our burners are unaffected by direct contact with SoyDiesel. However, the gasket materials we use shrunk in the presence of SoyDiesel and the adhesives dissolved. Also, the label adhesives dissolved.

D. At ambient temperature $\left(65^{0}-70{ }^{0} \mathrm{~F}\right)$ both fuels were close in performance, with SoyDiesel showing a tendency towards less smoke and $\mathrm{SO}_{2}$, while fuel oil showed a tendency towards a brighter flame.

With selections of compatible materials for our gaskets and label adhesives, our burners could easily be usable by both fuel oil and SoyDiesel."

Some observations may be made from their test results. The plastics that were reported as affected were made of vinyl, vinyl/PVC blend and neoprene. A key point that will be remarked on later is that they felt that the pump shaft seal behaved similarly with the biodiesel and the fuel oil. From the combustion test measurements, when the fuel was switched to $\mathrm{B} 100$ with burner settings unchanged, the $\mathrm{NO}_{\mathrm{x}}$ level in ppm was about $15 \%$ lower and the smoke level changed from a "trace" to "zero".

The Agricultural Research Service (ARS), the research agency within the United States Department of Agriculture (USDA), had announced its intention to use a blend of five percent biodiesel (B5) in its heating oil this past winter. ARS already uses a B 20 blend of biodiesel and petroleum diesel in a diverse fleet of 150 diesel vehicles [2]. Their experience in the heating application, where they will be using a $5 \%$ blend of biodiesel, that is B 05 , will be reviewed if the data is made available. 
A small number of tests were performed at Brookhaven National Lab prior to the start of this work. The results are reported in Krishna et al [4]. Primarily, they were steady state tests with measurements of performance variation with excess air. The results seemed to indicate that the NOx emissions were lower with the blends (see below). Otherwise, the combustion performances were similar with the blends and the fuel oil. One difficulty noticed and reported on in this preliminary tests, when firing neat biodiesel at high excess air levels, was the tendency of the flame proving control to shut off the system, even though the flame was lit and operation seemed normal. This was attributed to the 'less bright flame' when compared to that with fuel oil and the consequent response of the cad cell used to sense it. The photosensitive cell's dark resistance is higher and the control is set to shut off if it gets above a certain level.

\subsection{Present Project}

\subsection{Tasks}

The current project consists of the following tasks, omitting the report writing tasks:

Task 1: Fuel selection, acquisition, and characterization

In this task, the biodiesel will be acquired and blends will be prepared with No. 2 fuel oil to B10, B20, and B30 specifications. One blend, designated BK50 will be prepared with $50 \%$ Kerosene. These will be sent to a fuel testing laboratory to be characterized by measuring properties considered relevant to use in a space heating system. Discussions with burner system manufacturers will be used to establish problem areas of material compatibility.

\section{Task 2: Measure Ignition Performance and Material Compatibility}

Transient tests will be conducted to measure ignition performance in a conventional wetbase boiler using the blends and No. 2 heating oil for baseline. Again, if problem areas are observed, possible remedies will be identified through discussions.

At the end of tasks 1 and 2, one low-level blend will be recommended for further testing.

\section{Task 3: Measure steady state performance in a wet base residential boiler}

The chosen low-level blend and the BK50 and will be tested in a wet-base boiler for steady state performance. The cad cell will be checked by measuring the resistance to estimate the reliability of the control system.

\section{Task 4: Measure steady state performance in a commercial hot water boiler}

The two blends used in task 2 will be tested in a 2 million per hour commercial hot water/steam boiler in the laboratory. Steady state performance will be measured and compared with that obtained using No.2 fuel oil.

\subsection{Experimental Details}

Task 1: Biodiesel was obtained in a 55 gallon plastic drum from a manufacturer. The biodiesel was made, according to the manufacturer, from soy. The stock fuels used for making the blends and the blends were tested by a commercial laboratory for their properties. The biodiesel meets the draft ASTM specification, PS 121. The samples of biodiesel blends for analysis were prepared in $500 \mathrm{ml}$ lots. They were made on a volumetric basis using graduated cylinders to measure. The mixture was manually agitated for several minutes to obtain a uniform mixture. As the biodiesel and the stock fuels (kerosene and fuel oil) have different colors, the uniformity of color in the blended 
fuel was taken as one indication of thorough mixing. The stock fuels, the biodiesel and the blends were kept inside the laboratory at 'indoor ambient' temperatures. A maximum error of $3 \%$ of the value is expected in the making of the blends. Samples of the blends and of the stock fuels were sent for analysis to a fuels testing laboratory. The biodiesel was also tested at a second laboratory. The testing was done to appropriate ASTM standards where applicable.

Tasks 2 and 3: The test facilities in the oilheat research lab were used for these tasks. A three section, cast iron, wet base boiler was used for the tests. The boiler water is cooled by circulation through a plate heat exchanger, which in turn is cooled by building water. A modern retention head type burner with a pressure nozzle rated at 0.6 gallons per hour and fired at a pump pressure of 140 psi was used in the tests. Again, these conditions were maintained for all the blends and hence the fuel flows change slightly depending on the blend. The Burner operating conditions were set using the value of oxygen in the stack and of Bacharach smoke number with the No. 2 oil and were left unaltered for subsequent runs with the different blends. No changes were made to the nozzle, the ignitor, the cad cell and the control. Figure 1 is a photograph of the test set up. [4]

Constant sampling flue gas emission analyzers were used to measure the concentration of oxygen (paramagnetic measurement), nitrogen oxides (chemi-luminescent measurement) and carbon monoxide (infrared measurement) in the exhaust stack. A special sampling line built to meet the requirements of the analyzers is used to draw the sample from the stack. Smoke was measured using the ASTM \# D2156-80 method and a manually operated piston type sample pump.

The transient tests were started from a 'cold' boiler condition. The 'cold' condition was obtained by reducing the measured boiler water temperature to around 55 degrees $\mathrm{F}$ by prolonged circulation through the plate heat exchanger prior to starting the burner. It should be emphasized that this is not normal operation of the system, which cycles normally, under aquastat control, between $140^{\circ} \mathrm{F}$ and $180^{\circ} \mathrm{F}$ for boiler water temperature. Transient measurements of carbon monoxide and smoke were made during startup from 'cold' conditions. The analyzer output was fed to a data acquisition system for later analysis, while the smoke measurements were made using the manual system on a timed basis. B10, B20, B30 and BK50 in addition to No. 2 fuel and B100 were used in these tests.

The steady state tests were conducted by letting the boiler warm up to the normal operating temperature of about $140^{\circ}-150^{\circ} \mathrm{F}$. The Smoke number, NOx and the CO were measured at different excess air levels by changing the settings of the air damper on the burner and reflected by changes in the measured Oxygen concentration in the stack. Cad cell resistance was measured in separate tests for No. 2 fuel oil and B100.

Task 4: These steady state tests were conducted in a hot water boiler of 'commercial' size, which can supply hot water or steam and has a nominal rating of 1.8 million Btu per hour. A standard retention head burner was used with a nozzle rated at $7.0 \mathrm{GPH}$ and a $70^{\circ}$ solid cone spray. The fuel pump pressure was set at 150 PSI as recommended by the burner manufacturer and at this pressure, the fuel oil firing rate measured was $8.05 \mathrm{GPH}$ (1.12 million Btu per hour). The boiler steady state conditions were defined by steam output conditions of $5 \mathrm{psig}$ and $100^{\circ} \mathrm{C}$. The boiler was started up and warmed to the 
steady state conditions on \#2 fuel oil. The fuel input was then switched to the 'blend' under test and the measurements were taken when steady state was reached again. The tests were conducted with the same small positive draft in the stack of about 0.15 inches of water to avoid skewing of the stack measurements by intrusion of extraneous room air. The burner has different air settings that can be set to give different excess air levels for combustion and the tests were conducted at the same four settings for the stock fuels and the blends. The same set of instruments as above was intended to be used to make the measurements. However, the NOx analyzer failed after tests with a couple of blends. Later, another instrument of similar design (Chemi-luminescent measurement technique) was obtained. The limitations of the sampling system with this instrument prevented the simultaneous use of the above Carbon monoxide and Oxygen analyzers with this NOx analyzer. Hence, they were replaced by an instrument that is used for combustion analysis in residential and light commercial boilers and is based on electro-chemical sensors. Figure 2 is a photograph of the boiler set up. Only steady state tests were conducted. The startup with the blends were all 'hot starts', as the boiler had been warmed up on fuel oil.

\subsection{Results and Discussion}

\subsubsection{Blend Properties}

The results from characterization tests conducted by the outside test laboratory have been plotted in figures 3, 4, 5, and 6 below. Figure 3 shows that the flash point of the blends is quite close to that of the fuel oil even with $30 \%$ of biodiesel. In fact, from figure 5 , it can be seen that the $50 \%$ blend had only a $7^{0} \mathrm{C}$ increase over neat kerosene. This suggests that ignition with the blends would not be a problem and this was indeed apparent from the tests.

Figure 4 shows that the viscosity is more or less a linear function of the blend concentration and the values are within the ASTM limits of heating oil for even a 50\% blend with this sample of biodiesel. This suggests that the volumetric flow rate through the nozzle would be constant, as was indeed observed in the tests. It also suggests that the atomization characteristics would also be similar, though no measurements were made to verify this. One could infer from the similarity of the combustion behavior in the tests that this was probably borne out in practice.

Figure 6 seems to indicate that the measured pour point temperature increased more or less linearly with the biodiesel concentration. While the increase is expected, it is not obvious whether the operational problems with a particular blend would be consistent with the higher pour point temperature of the blend or different. A more detailed study and/or extensive practical experience with blends is probably needed to answer this question.

Table 1 gives the blend sulfur and nitrogen concentrations measured in a commercial test laboratory. The data need some explanation. The sulfur contents of the blends seem to be somewhat consistent with their mass concentrations in the stock fuels and the blending concentrations within reasonable measurement errors. As no sulfur dioxide measurements were made, there is no confirmation of the consistency. However, the first row of nitrogen data indicates that there is definitely inconsistency in the blend values. One would expect the values in the blends to be definitely a linear function of the values of the neat fuels by mass in the blend. However, this was not so and the samples were 
retested by the same laboratory. The next row in the table gives these results and it can be seen that they are quite different from the results from the earlier test. These seem consistent within reasonable measurement errors. The fuel nitrogen value is a significant number in view of the results reported below of an unexpected significant reduction in nitrogen oxides in the stack. The ASTM procedure used (D3228) does suggest in Note 1 that "This test method may not be applicable to certain materials containing N-O or N-N linkage". We do not know whether this could be one reason for the inconsistent results. In any case, it would seem that further work clarifying this aspect of the fuel analysis would be useful and possibly be beneficial to furthering the use of biodiesel as a fuel.

\subsubsection{Industry Discussion}

Discussions were held with personnel from the oil heat industry equipment manufacturers to obtain a perspective on what they see as potential problems in the use of biodiesel blends. Two burner manufacturers, one of whom has some experience with testing biodiesel in their burner and a leading pump manufacturer were contacted. The representative of one burner manufacturer felt that the only concern was burner set up with the blend. A more detailed response was provided by the engineering manager of the burner manufacturer who had tested biodiesel. He felt that potential problems with non metallic material in contact with biodiesel such as seals could be avoided by switching to Viton. He also felt that, for example, the specific design of the lip seal, in addition to the material of construction, could have a bearing on whether it failed functionally. He also felt that the erasure of labels, while not affecting performance, could lead to loss of marking, traceability etc. With regard to the problem of stability of the blends and of gumming, it was suggested that the use of a low level blend such as B20 would be a reasonable approach.

The representative from the pump manufacturer suggested that the current shaft seal used in their residential burner pumps were not good for use with biodiesel as it is constructed from Nitrile. He said the pumps manufactured in Europe for use with rapeseed biodiesel used Viton seals. He said they were going to start testing their pumps with biodiesel blends and would probably have a pump with a suitable seal developed in a year. He felt that Viton and Teflon were possible materials for use with biodiesel. He said that in previous testing, the seals had failed when the pump was tested with a B20 blend and so he could not recommend using the standard pump even with B20. However, he did not seem to recall the test results in the Beckett report [3], which had suggested that the pump seals had responded similarly in the soaking tests with \#2 fuel oil and with soy biodiesel. A brief discussion has been conducted with a large diesel fuel and heating oil distributor, who had expressed an interest in biodiesels. The intention was to sound out their possible participation in a field test under the NYSERDA sponsored part of the project. The company had not pursued the biodiesel procurement in view of the 'unfavorable' economics of the fuel. However, they may be willing to participate in a field demonstration. During the discussion, one of the questions that they were concerned with was the potential for biological activity due to the 'hygroscopic nature' of the fuel, as they termed it, and the consequential sludge/clogging problem. The problem exists with diesel fuel as well, especially due to condensation in large tanks and they use biocides to counter it. The problems of biological activity, of sludge formation and of the solubilization of existing sludge by the different solubility characteristics of the biodiesel 
are of concern for storage in large storage tanks, in tank trucks and in residential tanks. Graboski and McCormick [1] document that the biodiesel is less stable than petroleum diesel. Diesel engine experience suggests that filter replacement was needed sometimes due to clogging soon after switching to the blend from diesel. Clearly, these problems also tend to be less severe as the percentage of biodiesel in the blend is reduced [5].

Figure 7 is a schematic of a residential boiler fuel system and indicates the various components that can contain parts made of nonmetallic materials that come in contact with the fuel. This does not mean that all these parts are equally important nor does it suggest that any of them would necessarily be affected by biodiesel. The shaft seal in the pump would be the most significant part in terms of its duty and as alluded to above, the leading manufacturer has begun testing of their pumps with B20 and B100. Ordinarily, the common pressure nozzles do not have any nonmetallic parts. However, more recently there are manufacturers that have been using a check valve to control the fuel dripping after the burner shuts off. This valve might have an O-ring that might be affected by biodiesel blends.

\subsubsection{Ignition Performance}

The primary measurement during the transient tests is of Carbon Monoxide in the stack. The peak values and the duration of the transient are used as a qualitative measure of the ignition performance. Transient smoke was also measured, and partly in the nature of those measurements, did not indicate any significant differences between the blends and No. 2 fuel oil. The carbon monoxide measurements are shown below in figures 7 through 11. The broad features indicate that the blends of biodiesel and fuel oil or kerosene behave similarly. The peak values seem to be somewhat higher with biodiesel in the blend, a somewhat surprising result. It is conceivable that this may be an artifact of measurement, as the peaks occur for such a short time interval. However, for practical purposes, this short duration peak is not a significant concern. This similarity of the transient performance should be considered along with the similarity of performance at steady state reported by Beckett in reference 3, Krishna et al in reference 4 and the results of steady state measurements given here.

\subsubsection{Steady State Performance in a Residential Boiler}

The comparative performances will be reported in terms of carbon monoxide and NOx in the stack as a function of stack oxygen, which corresponds to excess air. As the biodiesel has about $12 \%$ oxygen, compared to practically zero for both fuel oil and kerosene, the blends will be at slightly higher excess air at the same stack oxygen level. Figures 12 through 15 compare the performance of the blends with fuel oil's performance. Broadly speaking, the addition of the biodiesel reduces the emission of carbon monoxide, probably as one would expect. Figure 16 is a composite of the NOx emission from all the blends and fuel oil. It is clearly evident that the NOx levels are significantly lower especially at the higher levels. This was somewhat unexpected, as the diesel engine data [1] indicate similar or slightly higher NOx with biodiesel blends than with petroleum diesel. Of course, the combustion situations are vastly different. This reduction in NOx in boilers, if confirmed, could be a significant advantage to the use of biodiesel (and blends) in such applications. While one could generally say this might be due to lower flame 
temperatures, a more detailed study would be needed to establish the reasons for it, especially in view of the apparent contrary results in engines.

It should be noted that during the runs for the measurements above, no control difficulties were noted with this burner/boiler combination and in the range of excess air levels tested. In view of the 'control' problem previously observed (see background section above) however, the cad cell resistance was measured with fuel oil and with B100, thus bracketing the performance with the blends. Table 2 below compares values with the two fuels. The cad cell resistances are very similar and hence one would not anticipate control problems with the blends in this burner and boiler as long as the starting transients are similar. As a matter of fact, we did not observe any such problems.

\subsubsection{Steady State Performance in a Commercial Boiler}

A general observation from these tests is that the smoke levels were lower with the increase in the amount of biodiesel blend in the fuel oil. This is, qualitatively, similar to the results in the residential boiler tests. The results for the NOx emission are given in Figure 17 below. We find that there is significant reduction in the NOx levels with increasing amount of biodiesel in the blend with fuel oil. The reduction is less significant with Kerosene because of the lower NOx levels. Still, B100 produces lower NOx under similar stack Oxygen levels than the Kerosene tested here. As stated earlier, these results are unlike those reported with diesel engines. Much more research needs to be carried out before these can be generalized and understood.

\subsubsection{Conclusions}

Blends of a biodiesel of 10, 20 and 30 percent by volume with no. 2 fuel oil and a blend of 50 percent biodiesel by volume with kerosene were tested for properties significant to burning in space heating boilers. The flash point increased only by $5^{0} \mathrm{C}$ over that for fuel oil for the $30 \%$ blend and by $7^{0} \mathrm{C}$ over that for kerosene for the $50 \%$ blend. This partly accounts for similar ignition behavior of the blends and the base petroleum fuels. The change in viscosity is almost linear with biodiesel fraction in the blend and even for the $30 \%$ blend, the value is within the ASTM specification for No. 2 fuel oil. From these fuel property considerations, one would recommend that blends of $30 \%$ or less could replace fuel oil with no noticeable changes in performance. This was borne out by the successful burning in a 'typical' residential burner and boiler. This success is measured by the fact that the system did not need to be adjusted to give performance similar to that with the fuel oil under steady state. Transient performance was also similar when measured by carbon monoxide and smoke emissions at startup. A blend of $50 \%$ biodiesel in stock kerosene was also tested with similar results. While similar tests with neat biodiesel were also conducted and are reported, use of $100 \%$ biodiesel is not contemplated and hence enough attention was not given to identify any potential problems.

Additionally, in steady state, the addition of biodiesel seems to lead to slightly lower carbon monoxide emissions and lower Nitrogen oxide emissions as well. The latter, while a welcome result, was somewhat of a surprise because results with biodiesel blends in diesel engines reported in other work indicate either similar or slightly higher NOx levels. Clearly, the combustion conditions are very different in the two cases. The reasons for this are not apparent without much more testing. 
As these systems operate in a cyclic fashion in the field, long term cyclic testing ought to be done. While this was not a task in the current project, the aspect of cyclic performance during startup was. The blends performed at least as well as the fuel oil as demonstrated by the results of the transient performance.

One of the concerns in the use of biodiesel in existing equipment, primarily diesel engines, has been the effect it might have on the non-metallic materials that come in contact with it. [6] Another concern, not unrelated to this, is the differences in 'solubility' characteristics of biodiesel from diesel fuel. These questions were not directly addressed experimentally in this project and no problems were encountered during the tests. The discussions with the people in the industry did not provide clear answers to all the concerns. In fact, one of the pump manufacturers has just started long term testing of their pumps on biodiesel blends. These concerns should be addressed by appropriate testing and studies in the future. Hence, caution at this stage seems warranted and it is recommended that a reasonably low level blend of $20 \%$ be used in field testing. This also seems to be the blend that other organizations such as the General Services Administration will be specifying for diesel engines.

The tests in the commercial boiler confirmed the similarity of steady state combustion performance of the blends and the base fuels. Again, the one major difference was the reduction in the stack values of NOx, which is more substantial than in the case of the residential boiler. The NOx levels are lower than in the residential boiler, which would suggest a lower 'average' flame temperature. However, the reason for the reduction with the blends is not apparent and needs more investigation.

\section{Recommendations}

The recommendations below follow from the work reported above.

a. A $20 \%$ by volume blend of biodiesel in fuel oil should be tested over several heating seasons in the field to establish practical use and identify any potential problems.

b. Laboratory testing should be carried out to answer concerns over effect on nonmetallic materials (elastomers) that are used in pump seals, valve seats etc. and appropriate changes determined if there are problems.

c. Research should be carried out to find the mechanisms for the reduction in NOx in boilers and establish scale up laws.

\section{References}

1. Michael S. Graboski and Robert L. McCormick, Combustion of fat and Vegetable Oil Derived Fuels in Diesel Engines, Prog. Energy Combust. Sci. Vol. 24, pp. 125-164 (1998)

2. www.Biodiesel.org, the website of the National Biodiesel Board (2001)

3. Research Report, R.W. Beckett Corporation, Unpublished (1993)

4. C.R. Krishna et al., Lab Tests of Biodiesel Blends in Residential Heating Equipment, Proceedings of the 2001 National Oilheat Research Alliance Technology Conference, BNL-52625 (2001)

5. Shaine K. Tyson and Paul J. Nazzaro, Biodiesel as a Heating Oil Blend Stock, Proceedings of the 2001 National Oilheat Research Alliance Technology Conference, BNL-52625 (2001) 
6. Gary B. Bessee and Joseph P. Fey, Compatibility of Elastomers and Metals in Biodiesel Fuel Blends, SAE 971690 (1997)

\section{Acknowledgements}

The support and the consistent guidance by the program manager, Dr. Shaine K. Tyson of the National Renewable Energy Laboratory is gratefully acknowledged. Geoege Wei provided the assistance in performing the experiments. Yusuf Celebi provided useful advice in the laboratory. Dr. Thomas A. Butcher and Roger McDonald provided the benefit of their years of experience in oil combustion. Gail Brown provided the administrative support. 


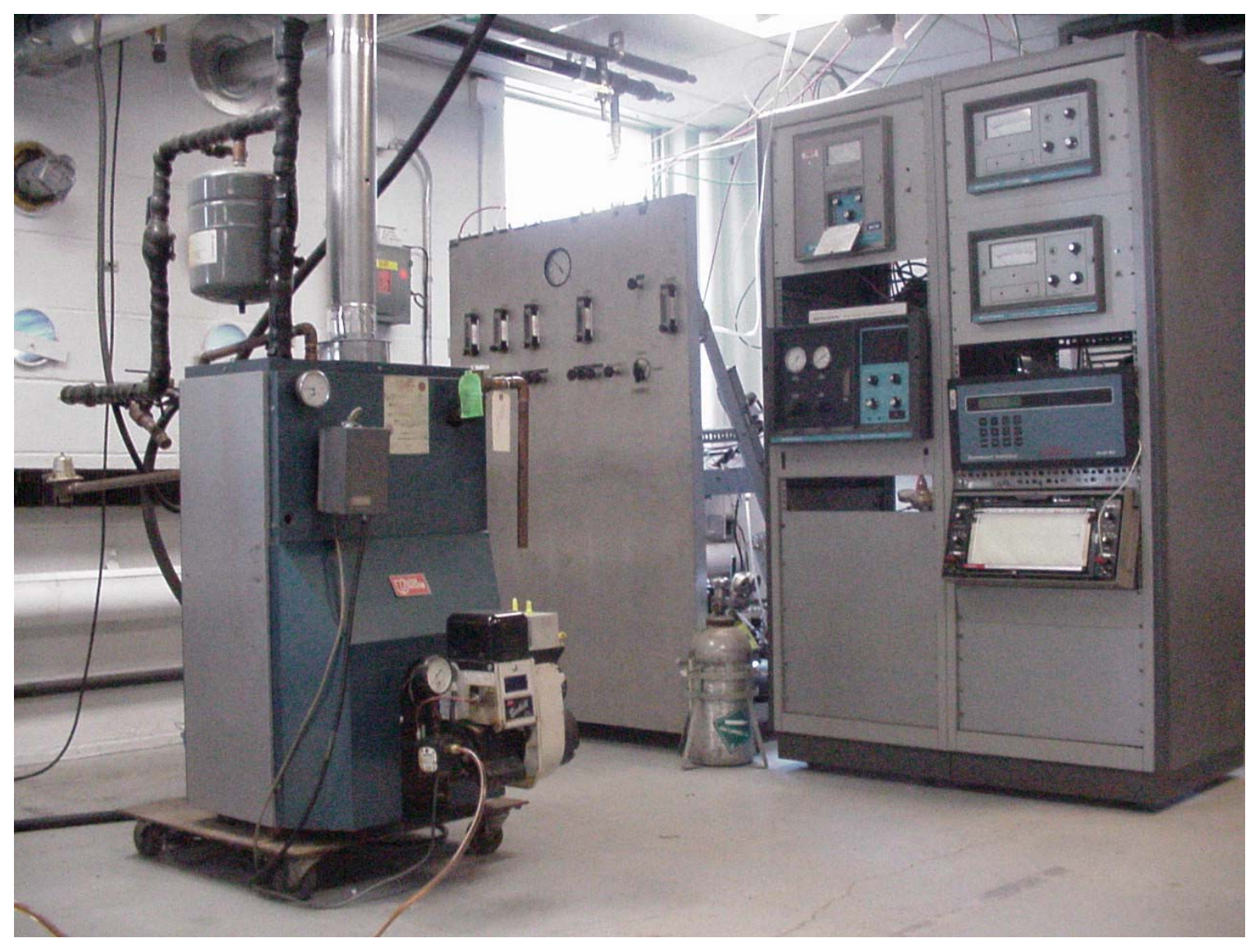

Figure 1. Test Setup for Transient Tests 


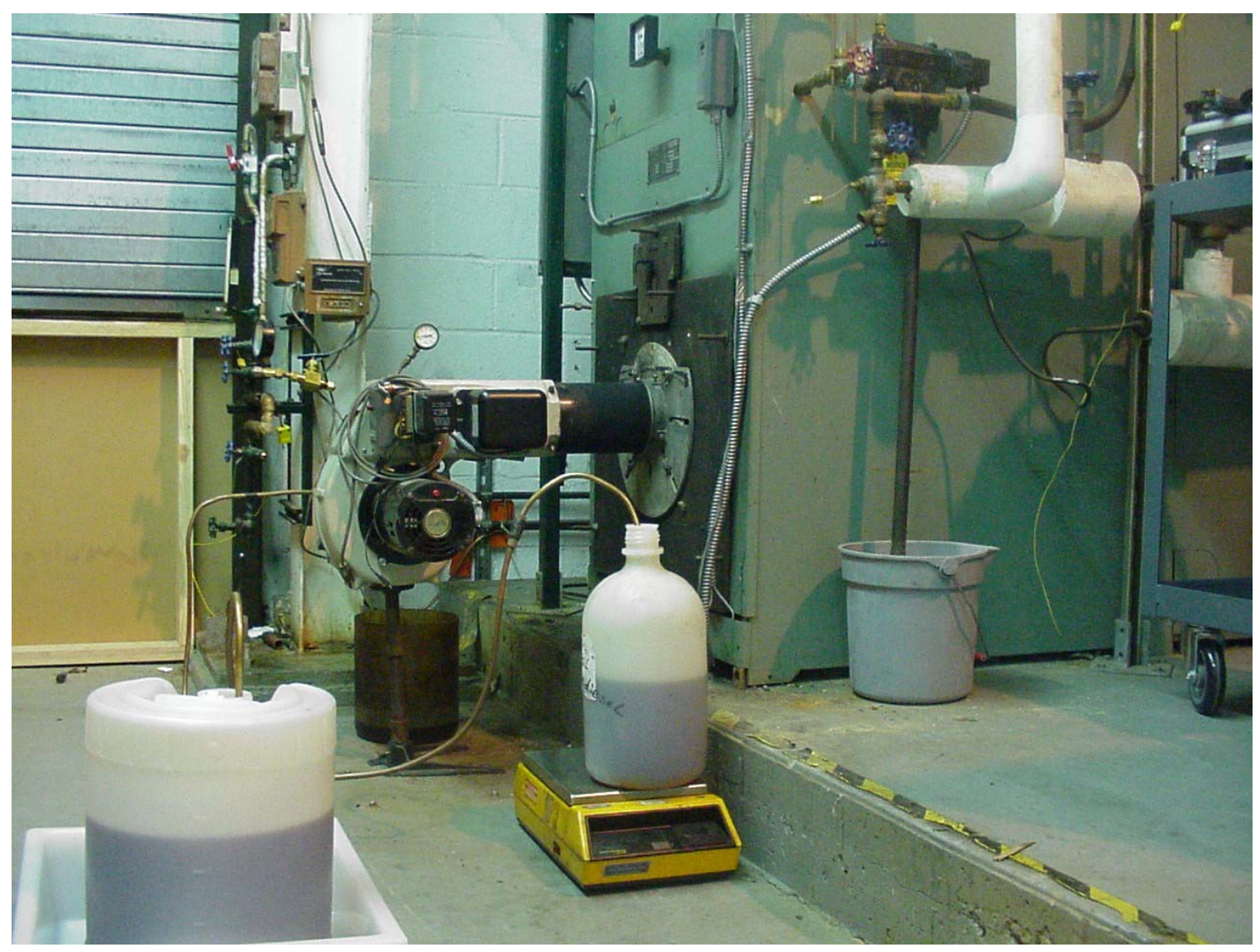

Figure 2. Commercial Boiler Set Up 
Flash Point of Heating Oil Blends

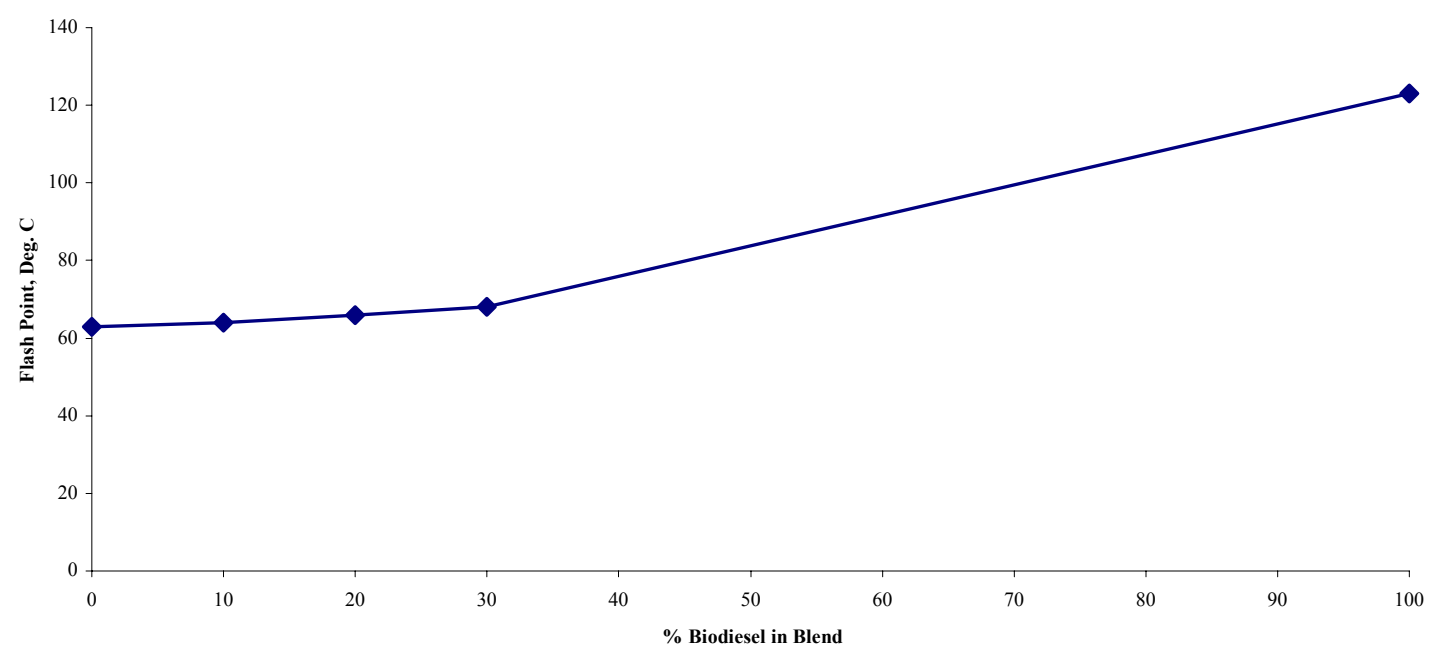

Figure 3. Flash point of Biodiesel Blends in Fuel oil.

Viscosity of Biodiesel Blends in Fuel oil

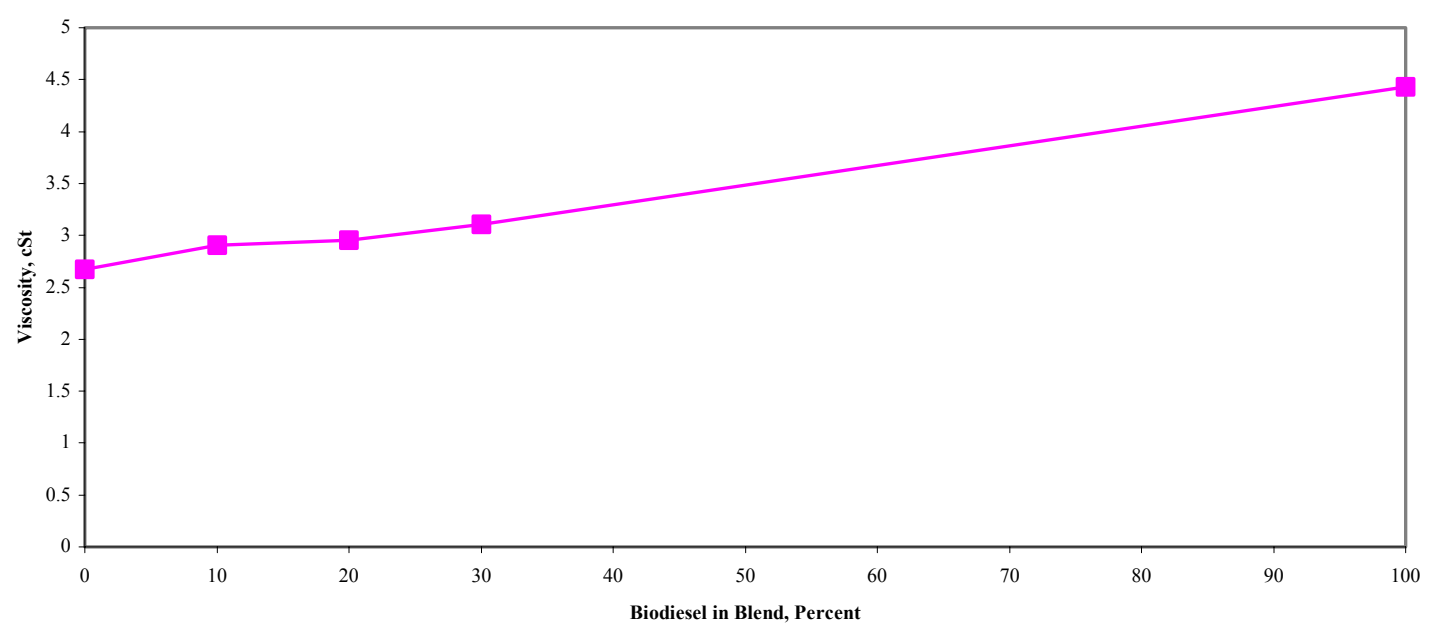

Figure 4. Viscosity Change with Biodiesel in Blend 
Flash points for Kerosine Blends

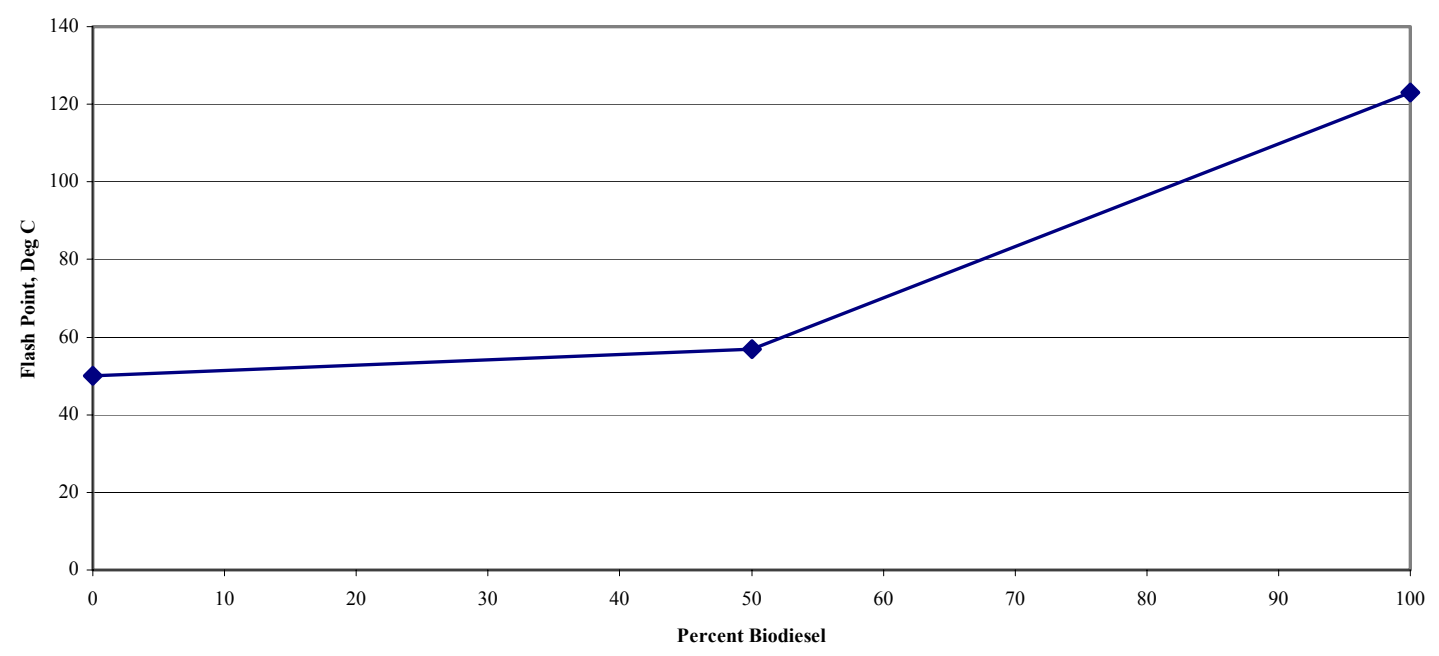

Figure 5. Flash Points for Biodiesel- Kerosine Blends

Pour Point of Heating Oil Blends

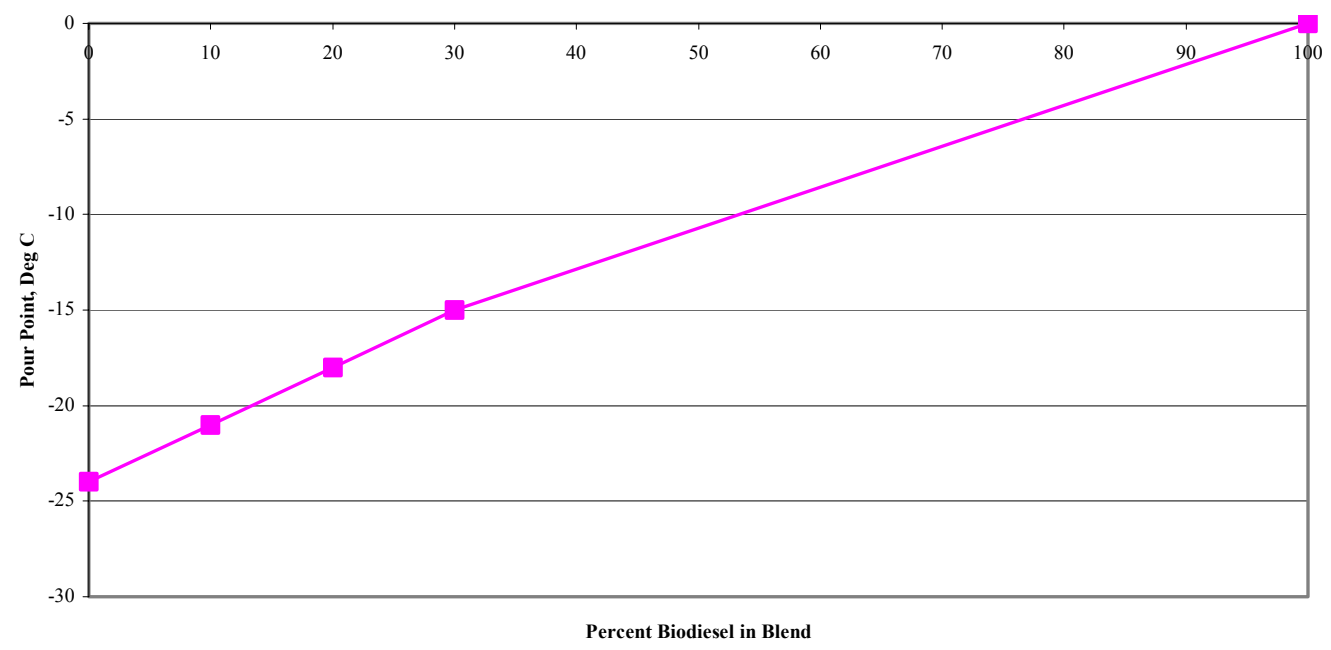

Figure 6. Pour Points for Biodiesel-Fuel Oil Blends 


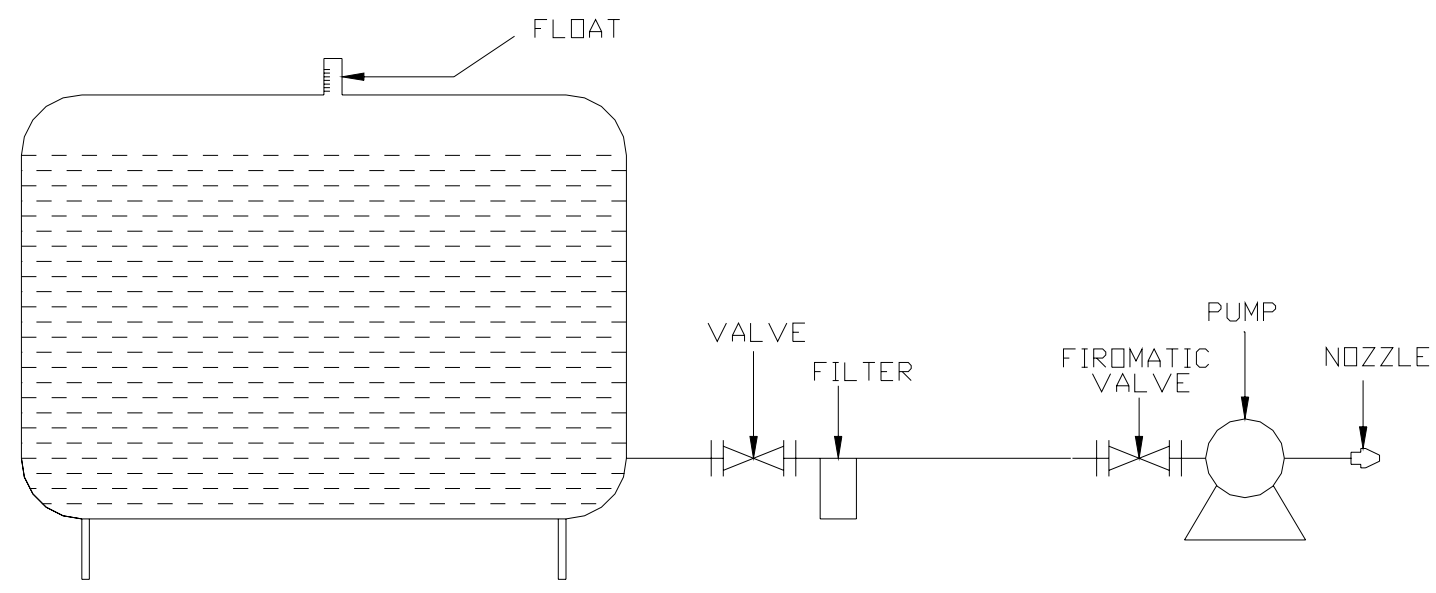

Figure 7. Schematic of a Residential Boiler Fuel System

Transient CO for \#2 Oil and B10

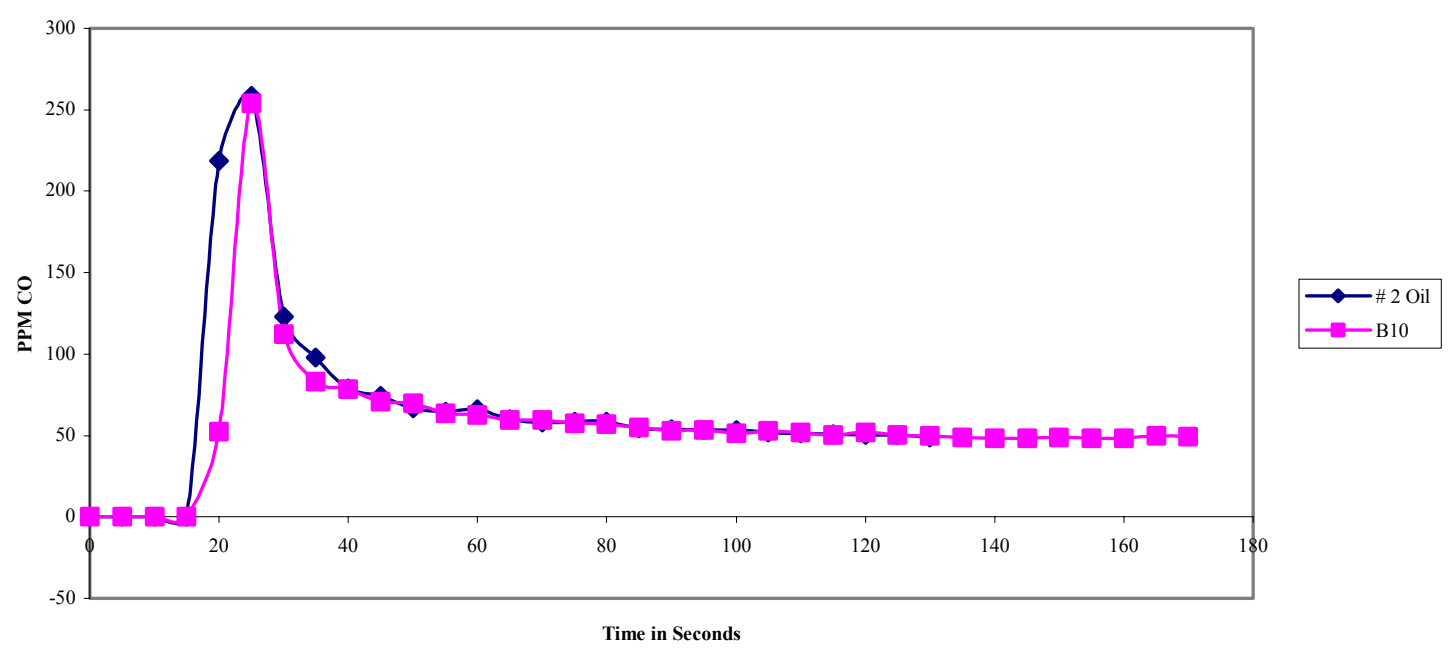

Figure 8. Carbon monoxide Transient for \#2 oil and B10 
Transient CO for \#2 Oil and B20

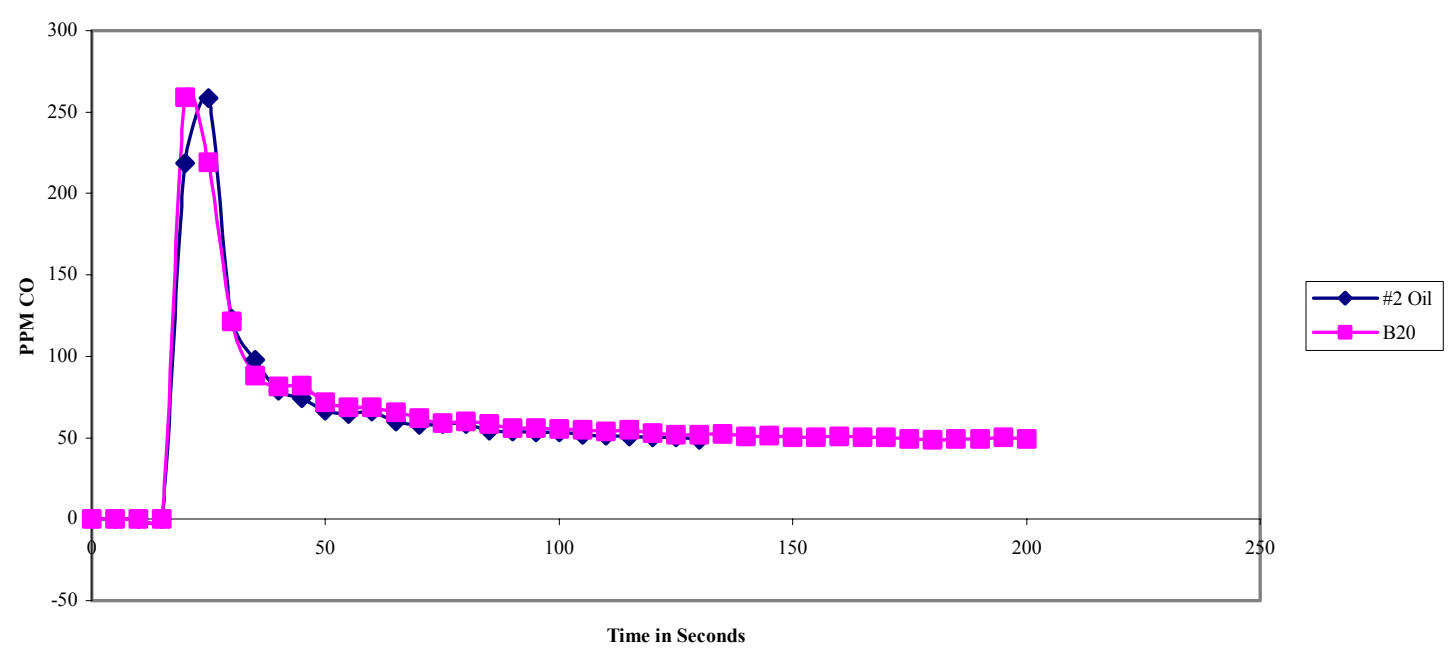

Figure 9. Carbon monoxide Transient for \#2 oil and B20

Transient CO for No. 2 Oil

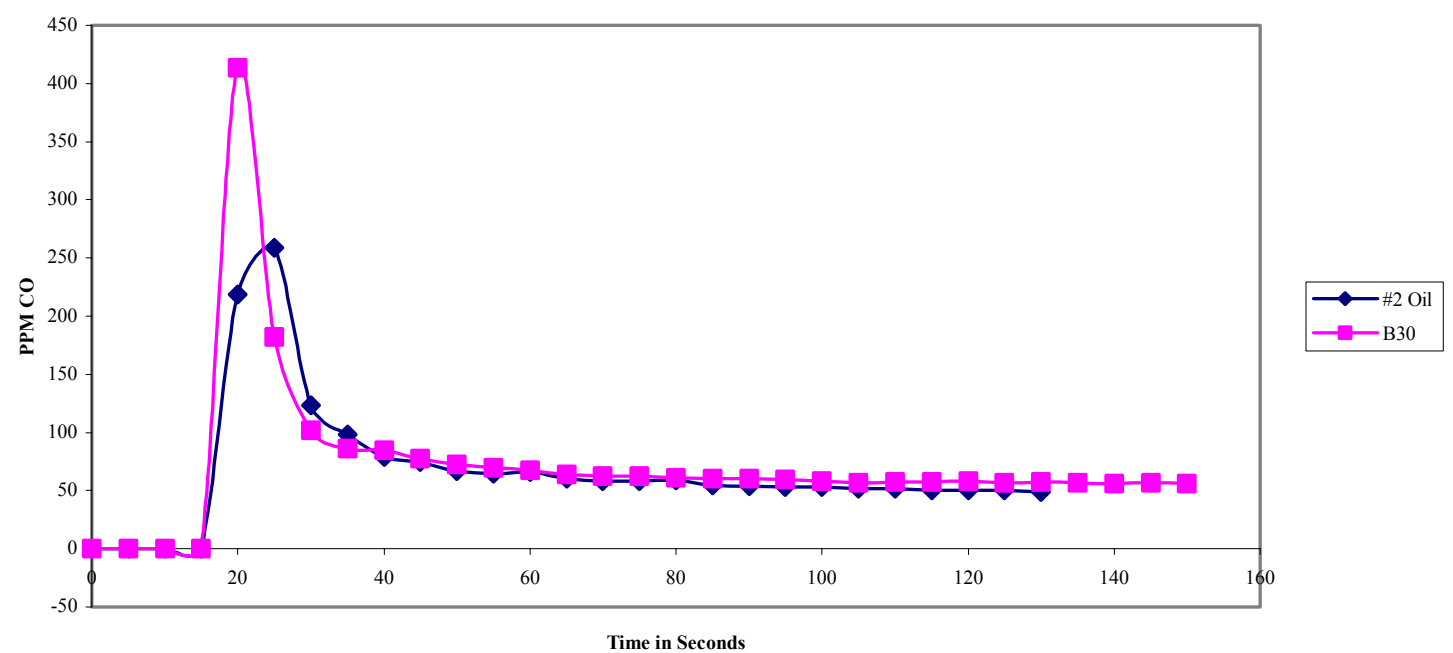

Figure 10. Carbon monoxide Transient for \#2 oil and B30 
Transient CO for \# 2 Oil and BK50

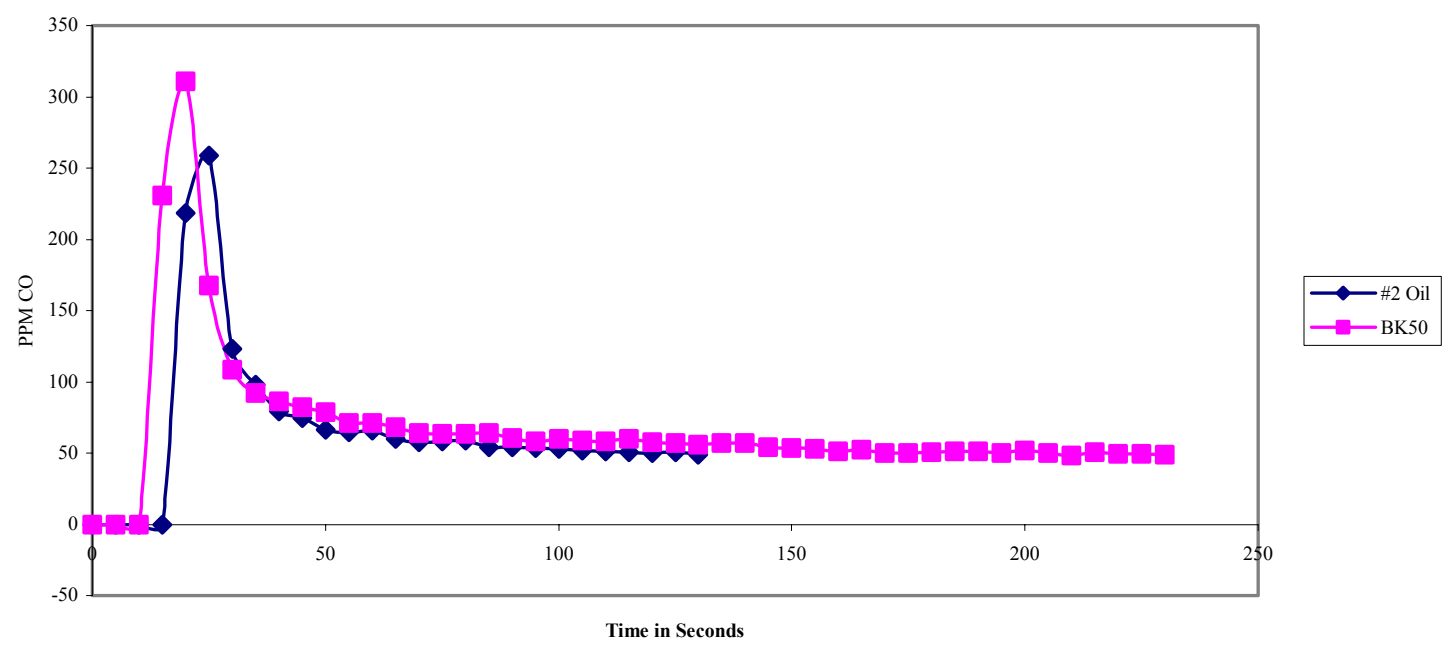

Figure 11. Carbon monoxide Transient for \# 2 oil and BK50 
Transient CO for \#2 and B100

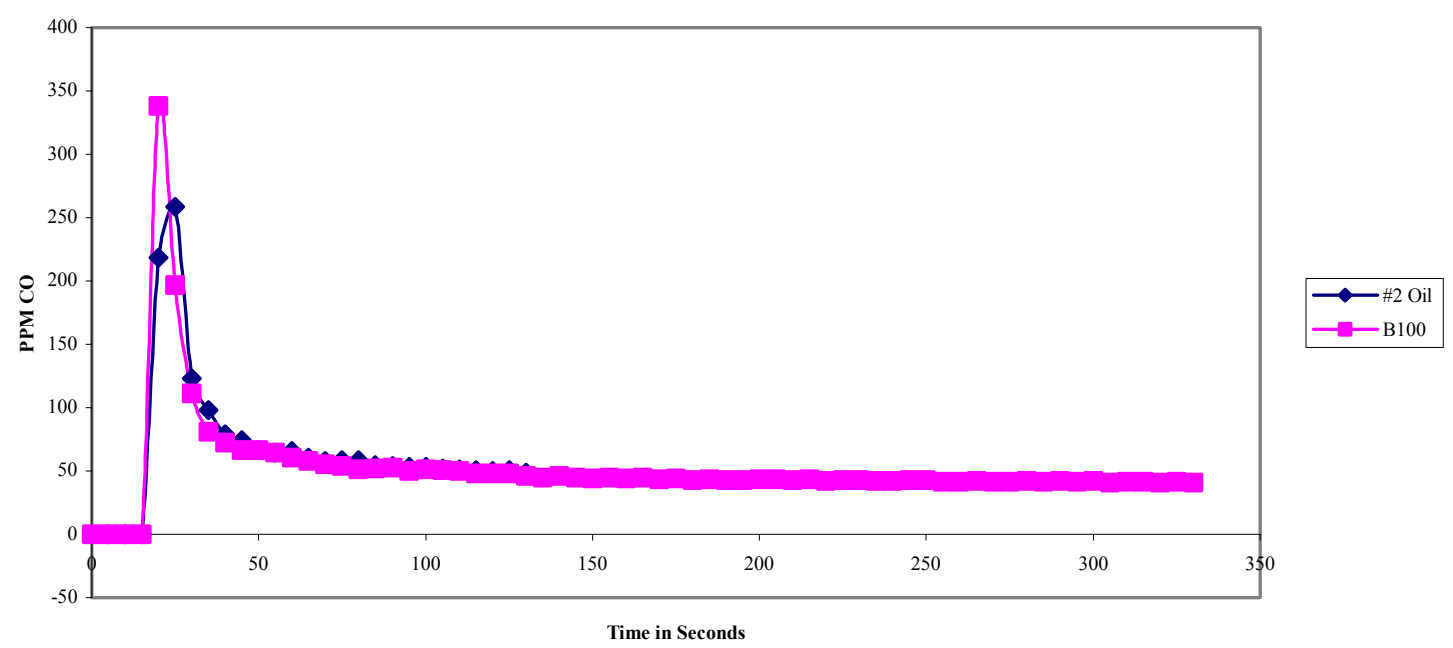

Figure 12. Carbon monoxide Transient for \# 2 oil and B100

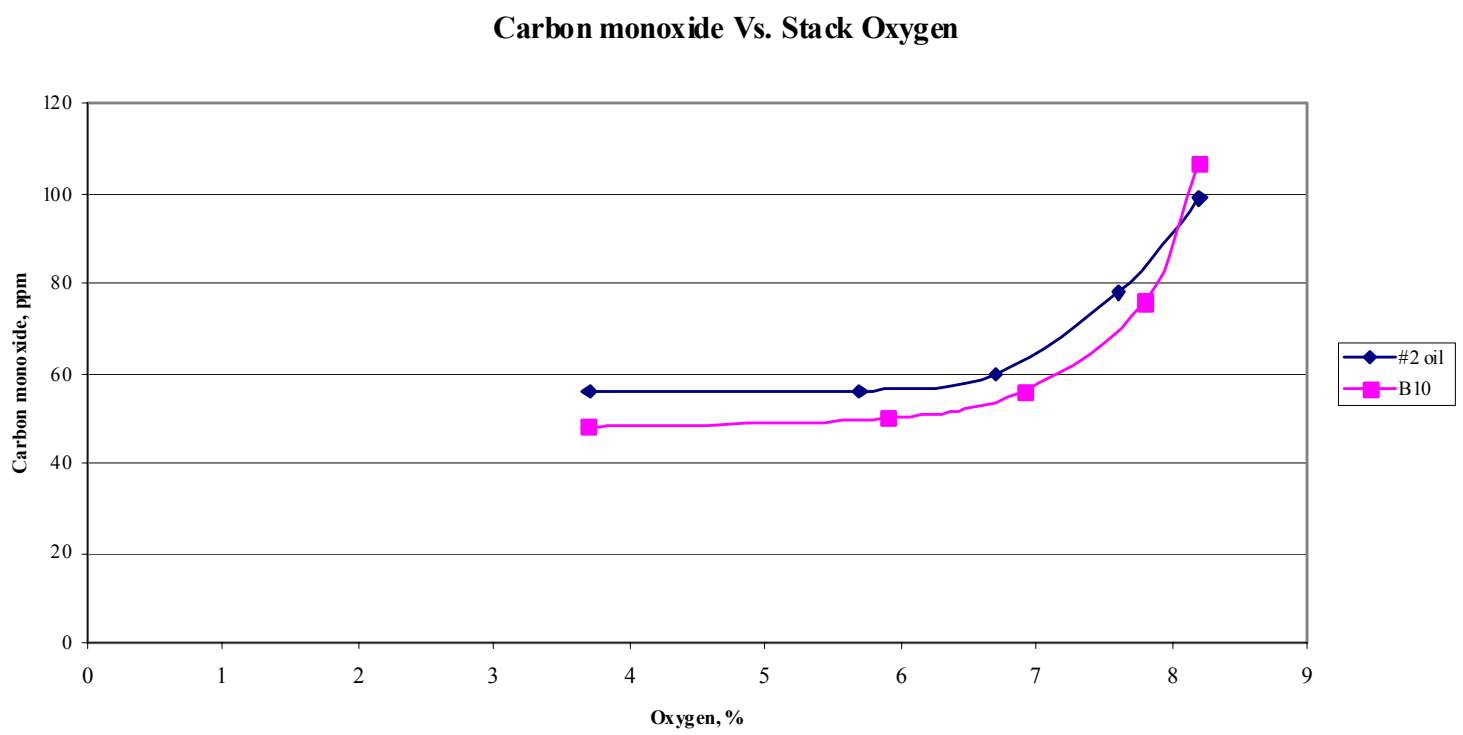

Figure 13. Carbon monoxide for B10 
Carbon Monoxide vs Stack Oxygen

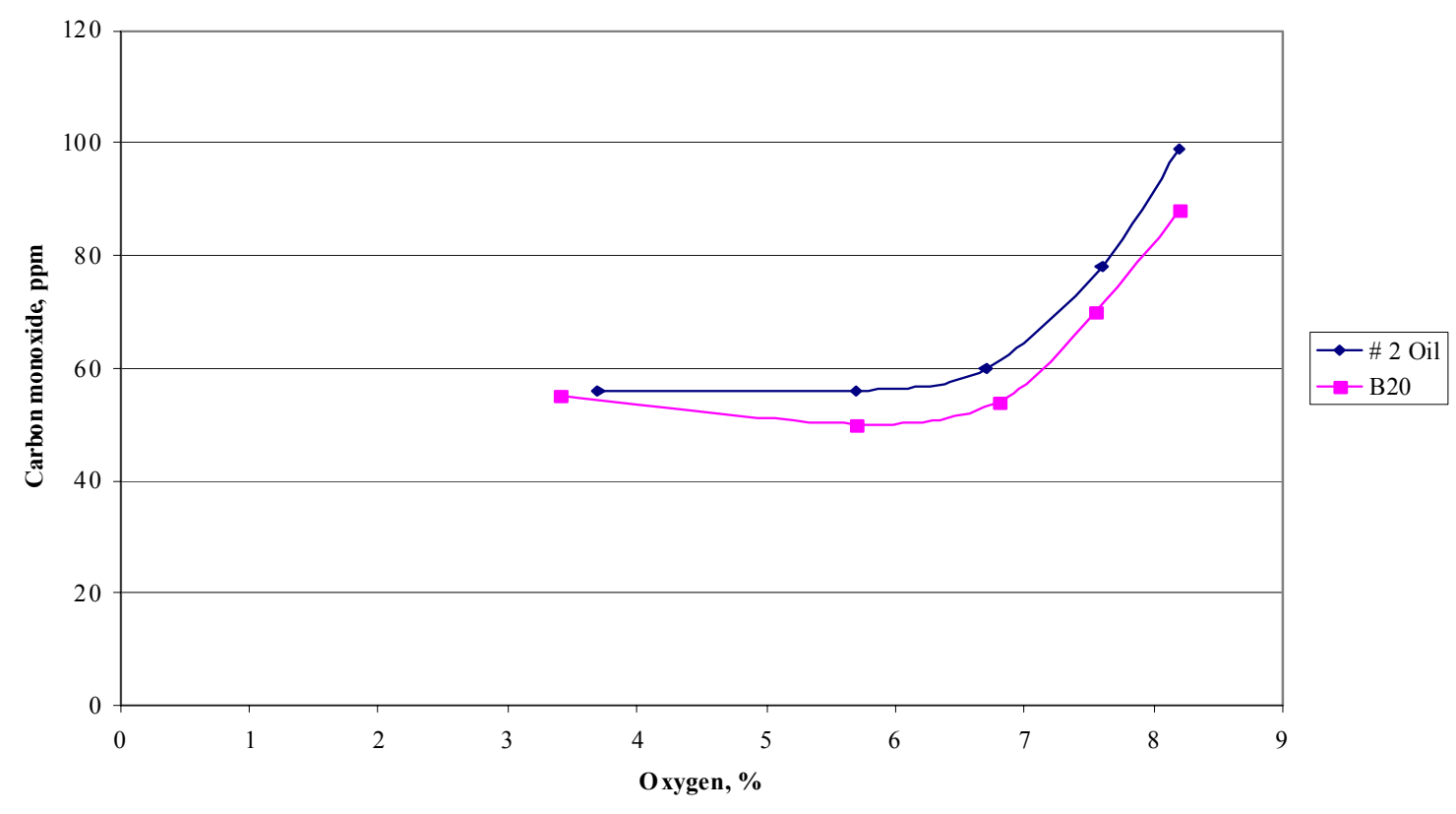

Figure 14. Carbon monoxide for B20

Carbon monoxide vs Stack oxygen

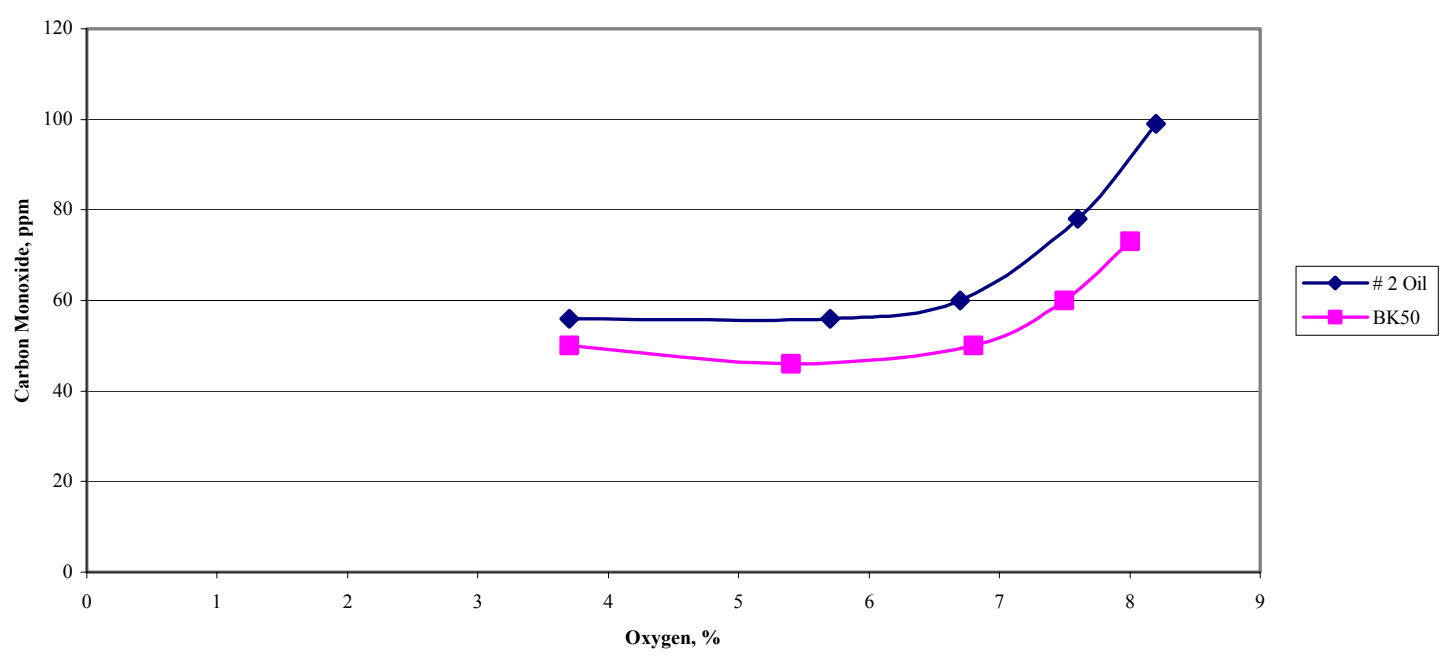

Figure 15. Carbon monoxide for BK50 
Carbon monoxide vs Stack oxygen

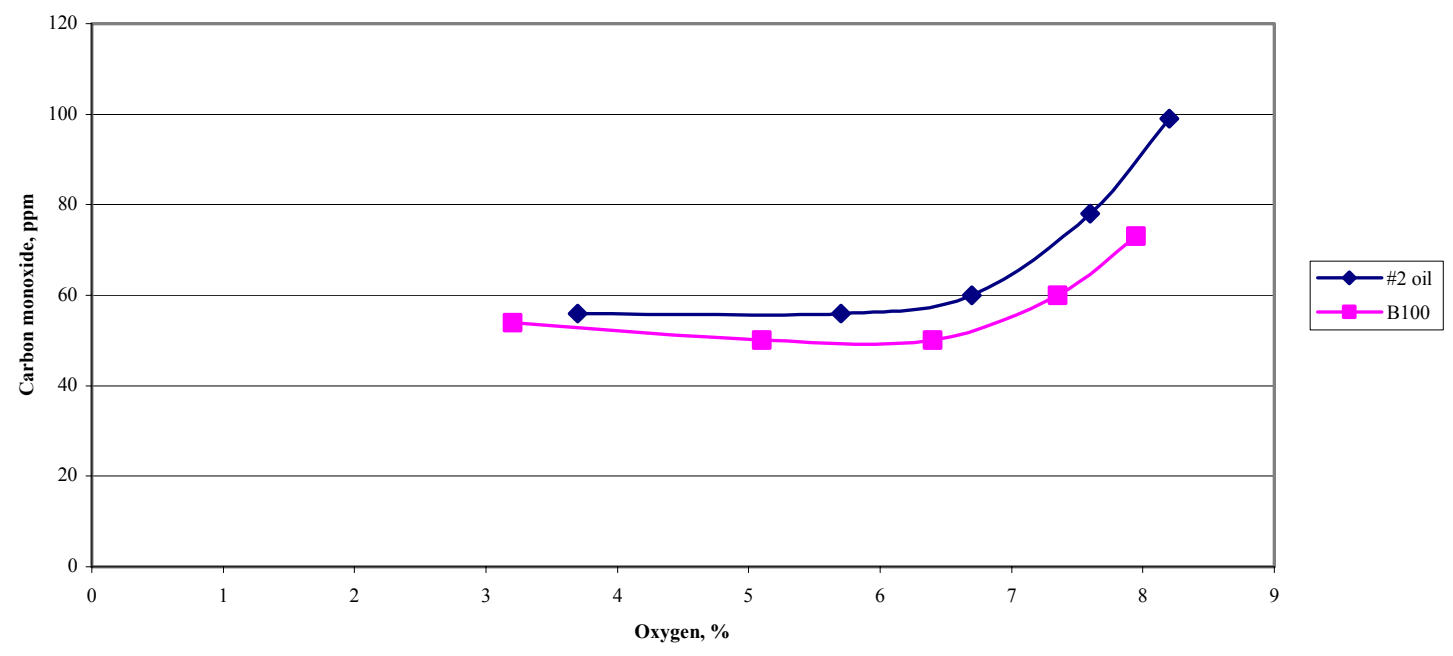

Figure 16. Carbon monoxide for B100 
NOx Vs Stack O2

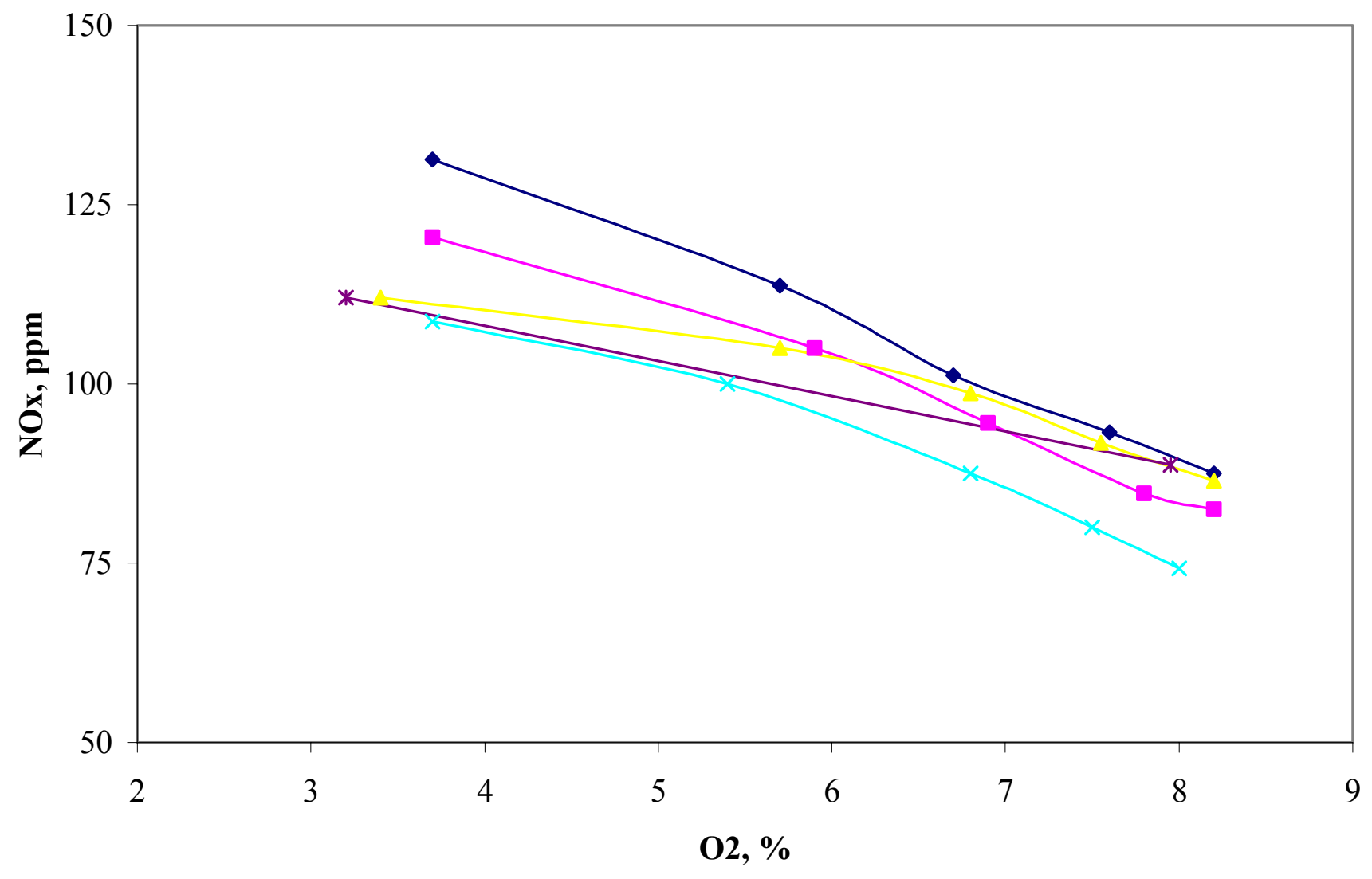

Figure 17. NOx in Residential Boiler 
NOX VS. O2 for Commercial Boiler

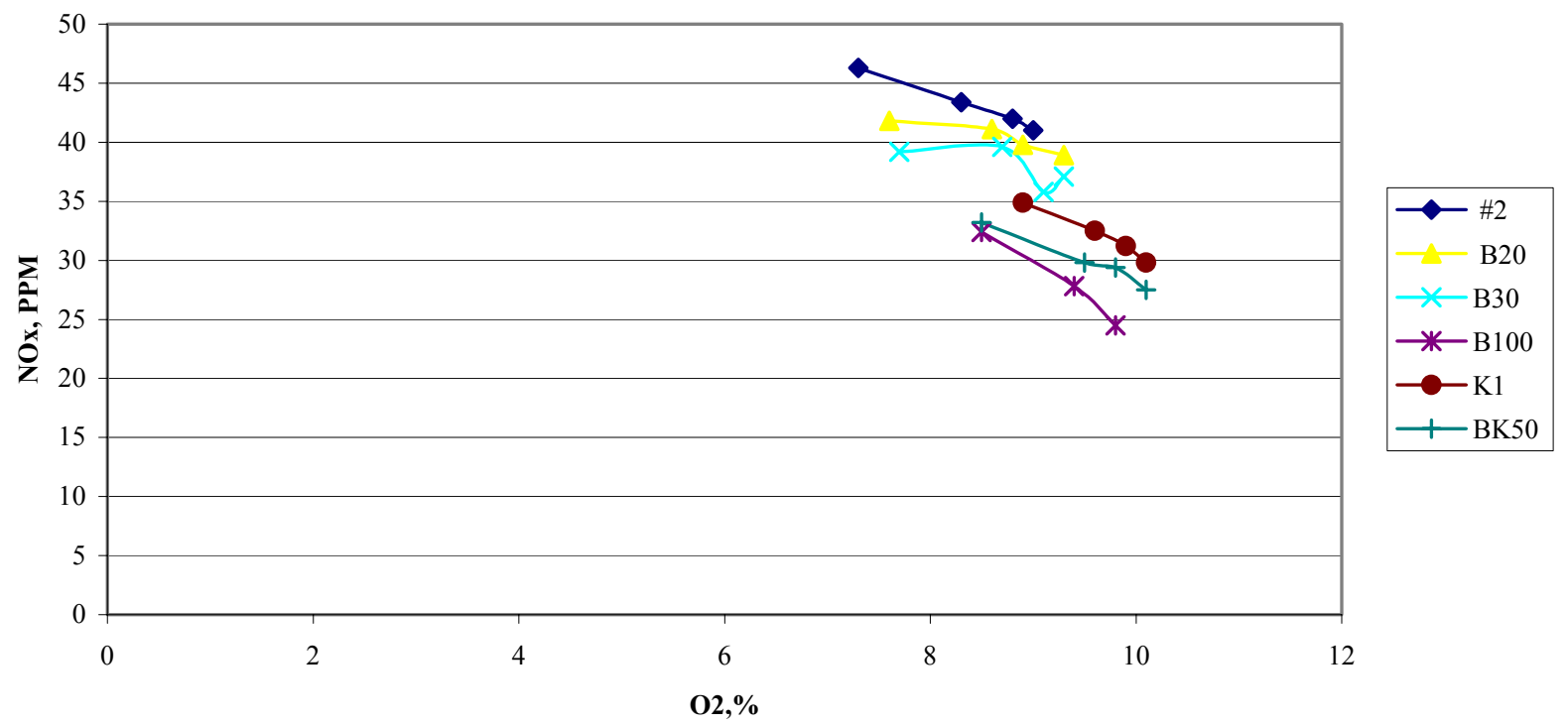

Figure 18. NOx in the Commercial Boiler 
Table 1. Sulfur and Nitrogen Content of Blends

\begin{tabular}{|c|c|c|c|c|c|}
\hline $\begin{array}{c}\text { Biodiesel in } \\
\text { Blend }\end{array}$ & $\begin{array}{c}0 \% \\
\text { (\#2 Fuel) }\end{array}$ & $10 \%$ & $20 \%$ & $30 \%$ & $\begin{array}{c}100 \% \\
\text { (Biodiesel) }\end{array}$ \\
\hline \% Sulfur & .3767 & 0.3234 & 0.2930 & 0.2518 & 0.0011 \\
\hline \% Nitrogen & 0.1789 & 0.1154 & 0.1232 & 0.1588 & 0.1061 \\
\hline $\begin{array}{c}\text { \% Nitrogen } \\
\text { (Retest) }\end{array}$ & 0.036 & 0.037 & 0.032 & 0.033 & $<0.03$ \\
\hline
\end{tabular}

Table 2. Cad Cell Resistance

\begin{tabular}{|c|c|c|c|}
\hline Fuel & Boiler Temp, ${ }^{0} \mathrm{~F}$ & Stack $_{2}, \%$ & Cad Cell, Ohms \\
\hline No. 2 Fuel & 160 & 4.9 & 960 \\
\hline B100 & 160 & 5.0 & 1000 \\
\hline
\end{tabular}

